Д. В. Капоровська, Л. С. Козуб

\title{
СПОСОБИ ДОСЯГНЕННЯ АДЕКВАТНОСТІ ПЕРЕКЛАДУ АНГЛІЙСЬКИХ АГРАРНИХ ТЕРМІНІВ
}

\begin{abstract}
Капоровська Д. В., Козуб Л. С. Способи досягнення адекватності перекладу англійських аграрних термінів.

Стаття присвячена дослідженню способів досягнення адекватності перекладу англійської сільськогосподарської термінології українською мовою. Особлива увага звертається на основні характеристики термінів, їх класифікацію, труднощі перекладу аграрної термінології, особливості використання перекладацьких прийомів.

Ключові слова: термін, аграрна термінологія, експлікація, транскодування, труднощі перекладу, перекладацькі прийоми.
\end{abstract}

Капоровская Д. В., Козуб Л. С. Способы достижения адекватности перевода английских аграрных терминов.

Статья посвящена исследованию способов достижения адекватности перевода английской сельскохозяйственной терминологии на украинский язык. Особое внимание обращается на основные характеристики терминов, их классификацию, трудности перевода аграрной терминологии, особенности использования переводческих приемов.

Ключевые слова: термин, аграрная терминология, экспликация, транскодирование, трудности перевода, переводческие приемы.

Kaporovska D. V., Kozub L. S. Ways to achieve the adequacy of translation of English agricultural terms.

The article deals with different ways of achieving the adequacy of translation of English agricultural terms into Ukrainian. Special attention is paid to the basic characteristics of terms, their classification, difficulties of translating agricultural terms, especially the use of different translation techniques. Term is a word or phrase of special (scientific, technical, etc.) language, which is created, received or borrowed for accurate expression of specific concepts and designation of special items. It is the word or phrase that means clearly defined concept of a special science, technology, art, social life, etc. The specific meaning of the defined term can be understood only through the context. The term is usually characterized by its consistency; availability of definition; monosemy; stylistic neutrality; lack of imagery, emotional coloring etc.

Agricultural terminology system of the English language is a complex, wellstructured, extensive system of terms, being constantly enriched with new terminological units which are connected with the development of technology, new approaches to crop production, breeding animals, as well as integrated and sustainable agricultural development. Agricultural term is considered to be a unit of language that expresses a specific concept that belongs to the theory and practice of agricultural science, characterizing and identifying it. There are many types of agricultural terms and 
terminological word combinations, which in the English language create the system of agricultural field terms. The methods of translation such terminological units are one of the most important subjects of research in the field of terminology.

Key words: term, agricultural terminology, explication, transcoding, translation difficulties, translation techniques.

Завдяки постійному розвитку науково-технічного прогресу, 3'являється необхідність удосконалення й оптимізації науковотехнічної комунікації, упорядкування та уніфікації термінології, пошуку ресурсів поповнення сучасних терміносистем. Мова $\epsilon$ динамічною, а тому система термінів постійно поповнюється новими лексичними одиницями, що викликають труднощі для розуміння i перекладу. Через підвищення ролі науково-технічного перекладу особлива увага приділяється перекладу термінів і всіх його складових.

У термінознавстві накопичений багатий теоретичний i практичний досвід дослідження термінологічних одиниць, які вивчалися на прикладі різних мов. Так, В. Комісаров досліджував функціонування термінів в англійській мові та способи їх перекладу [6], О. Павлова вивчала проблеми класифікації спеціальної лексики, виокремила й охарактеризувала основні класи й підкласи, визначила систему подібностей i відмінностей номінативних одиниць спеціальної лексики [8]. Поняття «спеціальна лексика» аналізувала О. Романова, яка теоретично обгрунтувала розмежування терміна i професіоналізму [9].

Задля виявлення специфіки англомовної аграрної термінології й особливостей iï перекладу українською мовою варто звернутися передовсім до витлумачення поняття «термін». Згідно 3 позицією О. Ахманової, термін - це слово чи словосполучення спеціальної (наукової, технічної i т. ін.) мови, яке створене, отримане чи запозичене для точного вираження спеціальних понять і позначення спеціальних предметів. Це слово або словосполучення, що означає чітко окреслене спеціальне поняття певної галузі науки, техніки, мистецтва, суспільного життя тощо [1, с. 95]. Таку думку поділяє чимало науковців, наприклад, В. Даниленко стверджує, що термін - це ๑ Д. В. Капоровська, Л. С. Козуб, 2016. 
слово (чи словосполучення) спеціальної сфери застосування, яке називає спеціальне поняття [3, с. 11].

Варто зазначити, що термін не називає поняття, як звичайні слова, а навпаки, поняття приписується терміну, додається до нього. У цій різниці вбачаємо відому конвенційність терміна: науковці тієї чи тієї царини домовляються, яке поняття вкладати в той чи той термін. Відповідно, конкретний зміст поняття, означеного терміном, буде зрозумілим лише завдяки його дефініції - лаконічному логічному витлумаченню, що вирізняє суттєві ознаки предмета або значення поняття, тобто його зміст і межі.

Основними способами творення термінів $є$ :

- зміна значення слова;

- творення неологізмів унаслідок словотворення 3 коренів та інших морфологічних елементів звичайної мови, що часто набирає форми кальок з іноземних мов;

- афіксація, яка представлена суфіксацією та префіксацією;

- семантичний спосіб (основними виявами семантичного термінотворення $є$ звуження значення, метафоричний і метонімічний переноси);

- запозичення (зазвичай з латинської та грецької мов) [7;12].

Переважання перших двох способів пов'язане 3 тенденцією до пуризму. Усі терміни мають низку характерних ознак, до яких належать: а) системність терміна (зв'язок з іншими термінами тієї чи тієї предметної сфери); б) наявність дефініції (визначення) більшості термінів; в) моносемічність (однозначність) терміна в межах однієї предметної галузі, однієї наукової дисципліни або сфери професійної діяльності; г) стилістична нейтральність; д) відсутність експресії, образності, суб'єктивно-оцінних відтінків [7].

Зазначені характеристики терміна доповнює Є. Скороходько, окреслюючи певні вимоги до термінів інформаційної мови. Окрім однозначності і формальної структури термінів, що повинна виражати зв’язки між поняттями, науковець вказує на стислість терміна і

-51- О Д. В. Капоровська, Л. С. Козуб, 2016. 
необхідність передбачити можливість: а) формальних перетворень термінів задля отримання нових термінів для позначення новоутворених понять; б) автоматичного перекладу термінів із природних мов на інформаційну мову і навпаки [10, с. 47-51].

Беручи до уваги класифікацію, запропоновану А. Суперанською, здійснимо систематизацію аграрних термінів за такими різновидами:

1. Терміни слова (виражені єдиним компонентом): wheatпшениия, stem - стебло, соb - стебло початка кукурудзи;

2. Терміни-словосполучення, серед яких вирізняються а) вільні словосполучення, де кожний з компонентів - термін, що може вступати у двосторонній зв'язок: combine harvester - комбайн, application off ertilizers - застосування добрив, biological test- біологічна проба; б) зв'язані словосполучення, де ізольовано взяті компоненти можуть і не бути термінами, а в поєднанні вони утворюють термінсловосполучення: headland - околиця зораного поля, general-purposeбагатоиільовий, problem-free - благополучний пункт;

3. Багатокомпонентні терміни, що складаються з трьох, чотирьох і більше компонентів: plate-and-flicker (distributer) - maрілчастодисковий висіваючий апарат, brothers-in-blood-однопометні брати, all-wheel-steer - рульове управління, щуо діє на всі колеса [9].

Стилістичними труднощами перекладу науково-технічних текстів, зокрема аграрних, українською мовою можна назвати переклад метафоричних термінів, образної та необразної фразеології, розмовні лексичні елементи та кліше, а також жанрові особливості науковотехнічних текстів. Для успішного розв'язання зазначених проблем i досягнення адекватності перекладу необхідно володіти знаннями та вміннями правильно застосовувати способи i прийоми перекладу лексичних елементів. У сучасній аграрній літературі перекладачі стикаються з такою проблемою, як багатозначність термінів, наприклад:

clone - 1) потомство рослинних або нижчих організмів, щзо утворилося шляхом вегетативного або клітинного розмноження;

(․ Д. В. Капоровська, Л. С. Козуб, 2016. 
2) абсолютна копія; 3) сукупність клітин або організмів, щзо походять від спільного предка иляхом безстатевого розмноження (мітозів); 4) сукупність однорідних органічних молекул dimock;

compost - 1) компост, складене добриво; 2) трунтова суміш (lizavetan); 3) розкладена органіка;

selection- 1) вибір; 2) добір, селекція; 3) невелика ферма; 4) ділянка землі під ріллю; 5) розпізнавання; 6) фрагмент на екрані, виділений за допомогою інструментів вибірки; 7) вибрані твори; 8) відбір як прочес в штучних і природних умовах dimock.

Для досягнення адекватності перекладу подібних термінів потрібно враховувати їх лексичне та граматичне оточення, тобто контекст. При перекладі складних слів або термінів використовують такі прийоми перекладу, як калькування, транскодування, описовий переклад та експлікація. Калькування - передача не звукового, а комбінаторного складу слова, коли його складові частини (морфеми) перекладаються відповідними елементами мови перекладу [11]. Наприклад: natural selecton-природний відбір; agricultural есоsystem - аграрна екосистема; agricultural activityсільськогосподарська діяльність.

Транскодування - це побуквена чи пофонемна передача вихідної лексичної одиниці за допомогою алфавіту мови перекладу. Цей прийом $\epsilon$ винятком у практиці технічного перекладу [7]. В аграрній сфері простежуються такі приклади: culture - культура; есоlogy - екологія; таіzе - маїс.

Експлікація (описовий переклад) - лексико-граматична трансформація, при якій лексична одиниця мови-оригіналу замінюється словосполученням, що дає пояснення або потрактування відповідної одиниці [6]. Експлікація є важливим і продуктивним засобом перекладу аграрних термінів, оскільки швидкий розвиток сфери сільського господарства не дає змоги багатьом термінам своєчасно знайти свої еквіваленти й закріпитися в мові перекладу. До описового перекладу висувають такі вимоги: 1) переклад повинен

-53- С Д. В. Капоровська, Л. С. Козуб, 2016. 
точно передавати основний зміст позначеного неологізмом поняття; 2) опис не повинен бути занадто докладним; 3) синтаксична структура словосполучення не повинна бути складною [4, с. 36]. За допомогою експлікації перекладають багатокомпонентні термінологічні словосполучення, наприклад: integrated pest management - комплексна боротьба із икідниками; contaminant- забруднююча речовина; overfertilization - вносити надмірну кількість добрив.

Аналіз особливостей перекладу складних термінологічних сполучень аграрної тематики показав, що найважливішою проблемою досягнення адекватності перекладу аграрних текстів $\epsilon$ передача вихідного змісту тексту за допомогою терміносистеми іншої мови, тобто правильне та доречне використання перекладацьких прийомів. Крім того, для досягнення адекватності перекладу, перекладач повинен володіти широким спектром знань із багатьох галузей та враховувати контекстуальний зміст тексту, що перекладається.

Отримані результати можуть сприяти подальшому поглибленому вивченню специфіки перекладу аграрної термінології.

\section{Література}

1. Ахманова О. С. Очерки по общей и русской лексикологии. / О. С. Ахманова. М. : Либроком, 2009. -296 c.

2. Білозерська Л. П. Термінологія та переклад : [навчальний посібник] / Л. П. Білозерська, Н. В. Возненко, С. В. Радецька. - Вінниця : Нова книга, 2010. $232 \mathrm{c}$.

3. Даниленко В. П. Семантическая структура специального слова и еe лексикографическое описание. / В. П. Даниленко. - Свердловск, 1991. - 155 с.

4. Карабан В. І. Переклад англійської наукової і технічної літератури : Граматичні труднощі, лексичні, термінологічні та жанрово-стилістичні проблеми / В. І. Карабан. Вінниця : Нова книга, 2002. - 564 с.

5. Колегаева И. М. Текст как единица научной и художественной коммуникации. / И. М. Колегаева. - Одесса, 1991. - 180 с.

6. Комиссаров В. Н. Современное переводоведение: [учебное пособие]/ В. Н. Комиссаров. - М. : ЭТС, 2001. - $424 \mathrm{c}$.

7. Кульчицька А. О. Переклад термінів [Електронний ресурс]. - Режим доступу : http://www.rusnauka.com/16_ADEN_2010/Philologia/68479.doc.htm

8.Павлова О. Терміни, професіоналізми і номенклатурні знаки (до проблеми (․ Д. В. Капоровська, Л. С. Козуб, 2016. 
класифікації спеціальної лексики). / О. Павлова // Проблеми Української термінології. - Л. : Вид-во Нац. ун-ту «Львівська політехніка», 2008. - С. 495.

9. Романова О. О. Спеціальна лексика української мови як об'єкт лінгвістичного дослідження : термін і професіоналізм. / О. О. Романова // Термінологічний вісник, 2013. - Вип. 2(2). - С. 4247.

10. Скороходько Е. Ф. Термін у науковому тексті./ Е. Ф. Скороходько. - К. : Логос, 2006. - 99 с.

11. Словник української мови : академічний тлумачний словник (1970-1980) [Електронний ресурс]. - Режим доступу : http://sum.in.ua/s/zhanr

12. Суперанская А. В. Общая терминология : Вопросы теории. / А. В. Суперанская, Н. В. Подольская, Н. В. Васильева. - М. : УРСС Эдиториал, 2004. - 248 с.

Стаття надійшла до редакиії 11.11.2016 p. 